\title{
Cadbury and a road not taken: Contestation over board design and development of UK corporate governance ${ }^{*}$
}

\author{
Donald Nordberg \\ Associate Professor of Strategy \& Corporate Governance \\ Bournemouth University Business School
}

\begin{abstract}
Since 1992, UK corporate governance has been guided by an evolving code of practice. This paper examines the debates during codification and revision, focusing on one issue, board design, and through a close reading of contributions to consultations, it shows the process had three outcomes: It valorised and institutionalised concerns of corporations and investors, but in ways legitimated disparate views and actors. It thus suppressed competing logics, but in ways that allowed them to resurface later. However, over time it failed to engage emerging voices in a rapidly changing market context, raising questions over its likelihood to retain legitimacy.
\end{abstract}

Keywords: Corporate governance, boards of directors, codes of conduct, UK, institutional logics, legitimacy

\section{Introduction}

A quarter of a century ago, the reforms entailed in the Cadbury Code set much of the world on a course towards a new type of corporate governance, shaking up and codifying the structures of corporate boards. It and subsequent iterations of what is now called the UK Corporate Governance Code are widely regarded as hallmark achievements in institutional development, incorporating guidelines tight enough to allow those sitting outside to track performance, with the flexibility to allow those inside to bend those structures to withstand a storm. The code has been seen as a tremendous success, if success is assessed by the degree of compliance and the effort norms of boards.

\footnotetext{
* This version of the paper has benefited from feedback from the British Academy of Management conference at Newcastle in 2016, where it was awarded the prize for the Best Full Paper in Management and Business History.
} 
In view of the financial crisis of 2007-09 and the long economic malaise that followed, the code might equally be considered a failure. It was born in an emergency, to prevent future major corporate failures like the near-simultaneous collapses of Polly Peck, Bank of Credit and Commerce International (BCCI) and the two listed companies run by Robert Maxwell, which had precipitated creation of the Cadbury Committee and then informed its work. ${ }^{1}$ But the failures of Northern Rock in 2007 and the next year of HBOS and Royal Bank of Scotland (RBS) ${ }^{2}$ were more severe in their consequences - for those firms, for the economic and financial system in which they operated, and for society at large - than anything the Cadbury Committee had to contemplate. Moreover, these three banks had largely adhered to the recommendations of the code, and where they did not comply, they provided an explanation.

What went wrong? That question has multiple contextual dimensions, ranging from increasingly global capital markets to institutional arrangements in banking regulation. Yet we can also ask in what ways the code itself and the processes of its development had contributed to the shortcomings so obviously manifest in the near-meltdown of the banking system.

This paper considers the latter question through a lens of how institutional change alters and then embeds control. The decision to codify corporate governance presented an opportunity to reconfigure control over corporations and the people who lead them. The code structured the previously unstructured work of boards. It established paths of accountability in a complex system of parties with interests in the corporation and its products, processes and performance.

Institutionalising certain solutions tends to favour one configuration of interests, while precluding attention to others. ${ }^{3}$ In so doing, it establishes and then embeds relationships, introducing at least the potential for rigidity. To avoid that, and account for the complexity in corporate governance, the UK code has practised regular revision, re-opening the debate and letting old, rejected recipes to get another hearing and a chance of emerging. In effect, it has institutionalised the opportunity for de-institutionalisation.

This makes the failure of the code to prevent catastrophic collapses all the more puzzling. How did the code, through repeated consultations, drafting and reformulations, fail to seek out other solutions, even as experiments, to address the risks and opportunities in the changing market and institutional contexts? To examine this question, this paper examines in detail a debate that raged during formulation of the Cadbury Code, ${ }^{4}$ and afterwards, over one 
particularly contentious issue throughout the history of corporate governance: the design of the board of directors.

Specifically, the contestation concerned the choice between the unitary board favoured, in differing constellations, in UK and US practice, and the two-tier board common in continental Europe. As we will see, a close reading of the contributions of interested parties to the consultations undertaken by the late Sir Adrian Cadbury in 1991 and 1992 shows that the issue was hotly debated, and that Cadbury himself was open to alternatives. While victory on the large issue then went to the incumbents, the corporations and mainstream investors, more peripheral actors won many concessions towards what central actors feared would be a two-tier board via the back door. Moreover, the issue never goes to rest. As the next great crisis in corporate governance in the early 2000s, it arose again, only to get pushed back, but with still more adaptations. And again, in the wake of the financial crisis later in that decade, a protracted, three-stage consultation focused on it again, with the same outcome, yet still without a move towards the sort of experimentation that Cadbury had contemplated.

The study's contributions lie, first, in showing the richness of the debate and how central actors drown out but do not extinguish disparate voices; second, how the processes of consultation and the opportunities for revision win broad acceptance among the affected social actors. However, set against radically changing market and institutional contexts, this analysis, third, raises questions about whether continuity in that code and the actors engaged in drafting may, over time, undermine the legitimacy of the institution the code has become.

Theoretically, it shows also how the process of consultation legitimates institutional logics the code then discards. Rather than more the more typical depictions of hybrid or blended logics in accounts of institutional change, ${ }^{5}$ this study shows how defeated logics remain suspended, ready to resurface when periodically the debate re-opens. That is, the process of codification and institutionalisation contains its own promise of deinstitutionalisation, allowing defeated logics to come back to life.

The rest of the paper is structured as follows: We start with brief discussions the context of the code and of institutional theory and logics. The paper sketches the development of the code and its impact in the UK and abroad. Then we explore the market and institutional contexts to appreciate their shape at the time of the initial codification and how they have changes in subsequent years. After a discussion of methods, we then look in details at the debate over board design, in 1991-92, in 2003, and then in the drafting of the 2010 UK Corporate Governance Code. This leads to a discussion of the code, consultation processes and the changing context to highlight how the code's evolving logic of corporate governance 
both informed practice and institutionalised. It also leads to questions about how well or poorly the process sits with the new context.

\section{The code in context}

In their analysis of how the language of the code has developed over time, Nordberg and McNulty ${ }^{6}$ demonstrate how Cadbury's initial emphasis on structures became layered in the early 2000s with stronger emphasis on board independence and a strengthening of the role of non-executive directors. Then, following the financial crisis of 2007-09, the code acquired another layer, stressing the importance of relationships, between directors and between firms and investors, which highlighted the shortcomings of both structure and independence. These changes of focus suggest, in effect, sedimentation of institutional logics as the code evolved

over time, with older logics persisting throughout. ${ }^{7}$ Nordberg and McNulty consider only the language of the code itself but not the voices heard during the debate, and how that debate reflected the market and institutional contexts of each time period.

The corporate governance literature has had surprising little to say about the processes of codification, however. A welcome addition is the account by Spira and Slinn, ${ }^{8}$ who draw upon the Cadbury Archive of committee notes and contributions from the consultations Cadbury conducted to explore how the Cadbury Code came about. They show a jostling among the various actors from the fields of corporations, investors, accountants, advisers, pressure groups and politicians. A rich and flavourful account full of personalities and anecdotes, their book stops short of theorising processes or drawing many implications for the practice of corporate governance, regulation or institution-building.

This paper employs techniques from both those studies to look behind the scenes at how the code developed over time, drawing on the language used by a variety of actors in the centre and on the periphery of the debate, and those in between. What the actors say during consultations over the code help to surface the underlying logics they seek to embed in the new institution of the code and then defend over time.

\section{Institutions and their logics}

During the period under study, UK corporate governance moved from what institutional scholars terms a case of mimetic isomorphism, ${ }^{9}$ in which boards copy what they see other boards doing, to a code of practice, setting out a body of rules - binding and yet voluntary that become widely accepted. As we will see, the jolt to the status quo through corporate 
failures presents an opportunity to examine what rules apply, and why; that is to consider what logics underlie attitudes taken for granted.

Institutional logics have been defined as 'broad cultural beliefs and rules that structure cognition and fundamentally shape decision making and action in a field ${ }^{10}$ or the "principles, practices, and symbols' that shape how reasoning takes place among actors adhering to an institution. ${ }^{11}$ Green argues that institutional logics work like syllogisms, but with terms of the argument increasingly suppressed the more taken-for-granted the institution becomes. ${ }^{12}$

These logics are based in assumptions held in high level society orders; among them markets, corporations and the state are particularly relevant to this study. These orders give rise to logics that, like the organising principles in Puxty et al.'s study of accountancy. ${ }^{13}$ Where and when orders intersect, those taken-for-granted assumptions can conflict and the resulting contest of ideas may give rise to new institutional arrangements with new, blended or hybrid logics. Corporate governance scholars write about logics including shareholder value and managerialism ${ }^{14}$ among others, which then inform the choices of boards. Codification offers an opportunity to rethink logics taken for granted.

\section{Development and impact of the UK code}

The UK Corporate Governance Code is an evolving institution that has changed the conduct of boards of directors and institutional investors in many ways. It has also influenced thinking in many countries, ${ }^{15}$ in Europe and further afield; not only in Commonwealth countries with institutional similarities to the UK, but also in civil law jurisdictions ${ }^{16}$ and in the self-regulatory codes of the US stock exchanges. ${ }^{17}$ Through its various revisions the code has prescribed mechanisms to foster good governance, including the separation of the role of CEO and chairman; the use of independent, non-executives directors; and creation of committees to consider remuneration, audit and nominations. The code valorises the unitary board of UK practice with its combination of executive and non-executive directors, while shifting the balance between them over time, with non-executives gaining a steadily more important role. In so doing it lays aside the idea of a continental European-style, two-tier board, though as we will see only after a fight and after concessions that seek to achieve somewhat similar aims. 


\section{A shifting market and institutional context}

The UK has traditionally had an open, internationally minded capital market, yet it was for many centuries also a market of close personal relationships. Even in the $21^{\text {st }}$ Century, newspapers write about 'City grandees' serving as company chairmen or heads of government enquiries into various economic and social problems. ${ }^{18}$ Sir Adrian Cadbury, scion of the Cadbury family who created and many years led the chocolate maker of that name, was among them.

The Cadbury Committee came into existence to examine what went wrong in what seemed at the time a stunning set of seemingly unrelated corporate failures, specifically with a mandate to restore the credibility of corporations and the 'financial aspects of corporate governance'. 19 Was there something wrong, systemically, with the corporation, with accounting and audit, or with the relationship between companies and investors? If so, then changes in company law, in accountancy principles or audit rules, or in the property rights of shareholders might forestall future such cases. That is, changes in institutional arrangements, in particular the formal institutions of law and regulation, might be needed. But the committee was a creature of markets, in particular of the London Stock Exchange and the accountancy professional bodies, not government, ${ }^{20}$ suggesting a desire to find less prescriptive alternative, one in which a new logic might inform a way of thinking that could become widely accepted and eventually taken-for-granted. ${ }^{21}$

In the quarter of a century since then, much has changed. At the time of Cadbury, UKbased pension funds, insurance companies and collective investment vehicles held the majority of shares listed on the London exchange. By 2012, foreign investors would dominate ownership of UK-listed companies, including sovereign wealth funds ${ }^{22}$ as well as conventional investors from abroad. ${ }^{23}$ Both domestic and foreign investors now also include hedge funds and other alternative investment vehicles, with different ambitions, clients, time horizons and methods of interacting with corporations. ${ }^{24}$

Law and regulation have changed as well. London, once famous for its reliance on a system of professional self-regulation moderated by the 'raised eyebrow' of the governor of the Bank of England, ${ }^{25}$ saw gradual, then transformational change. The 'Big Bang' market reforms of the late 1980s undermined cosy relationships in the 'City', as the financial district is known.

With a change in government in 1997 came a wholesale change in the regulatory environment. At the retail end of the market, lawyers and accountants lost their authority to 
manage investments of wealthy clients unless they earned separate qualifications from the Financial Services Authority (FSA). The London Stock Exchange, a mutual organisation owned by market actors in 1992, became a public company listed on its own exchange. It was forced to shed its regulatory arm, the UK Listing Authority, which became part of the new FSA, which also subsumed a raft of self-regulatory regimes for pensions, investment, lending. The Financial Reporting Council (FRC), once a creature of the accountancy profession, became a governmental agency.

The so-called 'New Labour' government of Tony Blair embarked on a reform of Company Law in 1998, shortly after coming to power. It was a task it did not complete until 2005, owing to resistance from the City and corporations to its plan to define director duties for the first time in statute and disagreements within the party. Opening the door of law reform gave an opportunity to reconsider the question of unitary and two-tier boards. In the end that door never opened very widely, however. Director duties, when eventually codified, required boards to give 'due regard' to employees, suppliers and customers. But its embodiment of 'enlightened shareholder value' it endorsed shareholder primacy, ${ }^{26}$ rather than the more radical changes many 'Old Labour' activists advocated.

Further changes would come following the election of a Conservative-Liberal Democrat coalition government in 2010, breaking the FSA in two and putting both wings under the Bank of England. But the die remained cast: Regulation was a formal institution of the state; markets were global and increasingly unattached from the UK, except for the not-so-small matter of residual risk in cases of catastrophic failure, as taxpayer-funded rescues in the banking sector demonstrated.

UK law and regulation depend upon and inform what emanates from the European Union, where this period saw substantial change. Among the measures adopted were a string of reforms to voting rights for shareholders, including an easing of constraints on crossborder voting and the power of shareholders to reject remuneration policies. These changes transferred power from corporations to investors, legitimating the logic of shareholder primacy at the expense of non-investor constituencies as well as corporate boards.

Within changing market and institutional contexts, the process of codification of corporate governance means that what discretion remains over the control of corporate resources is a contest between other actors, and notably those in the centre of the field: corporate boards and institutional investors. After a discussion of methods, we consider what took place as the UK code took shape over the issue of board design. 


\section{Methods}

Following the approach of Nordberg and McNulty, ${ }^{27}$ this study focuses on the debates over three versions of the UK code, the Cadbury Code ${ }^{28}$ the post-Enron Combined Code of $2003,{ }^{29}$ and the renamed UK Corporate Governance Code. ${ }^{30}$ The code has changed on several other occasions, but this selection is justified because it considers the three times the consultations took place in a time of a perceived crisis in corporate governance, when willingness to entertain substantial change was strong.

The Cadbury Committee convened following several failures of prominent UK enterprises. The 2003 code and the Higgs Review that inspired it followed corporate governance failures in the US (Enron, WorldCom and many others), the Netherlands (Royal Ahold), Italy (Parmalat) and Australia (HIH), as well as all many dot-com technology flotations around the world in the late 1990s. Then, after the near collapse of the global banking system and the home-grown problems at Northern Rock, RBS and HBOS, the UK government commissioned the 2009 Walker Review of governance of financial institutions. ${ }^{31}$ The Financial Reporting Council, which regulates accountancy and audit, pulled forward a planned review of the corporate governance, completing an 18-month and three-phase consultation in 2010 .

Specifically, the consultations analysed for this study were 1) the formal submissions following the Cadbury draft in May 1992, as well as related material from before the draft; 2) the brief, 'fatal flaws only' consultation after the Higgs Review in 2003; and 3) all three phases of the 2009-10 consultation. Some of the Cadbury documents were examined online; those not digitised were viewed at the Cadbury archive at the University of Cambridge (referenced below with numbers beginning with CAD). Some of the contributions in 2003 were provided for this study by the Financial Reporting Council, others were discovered through web searches in an inactive but still public directory on the FRC website. Those for the three 2009-10 consultations were harvested from the FRC website after the consultation periods ended.

The consultations all involved more than just formal submissions. Interviews, informal gatherings and public meetings of interested parties took place (for a summary of the consultation process, see Appendix 1). While no systematic record of these exists, it seems reasonable to assume that those involved in drafting the code itself would have paid close attention to written evidence. In the case of Cadbury Report, the archive gives evidence of that, as the discussion below describes. However, notes by Sir Adrian Cadbury indicate that 
one non-submission is of particular interest, and it has been included for this study: An opinion column in the Financial Times (FT) by Sir Owen Green ${ }^{32}$ clearly affected the committee's thinking; it was noted in internal papers of the Cadbury Committee and cited with approval by several important external contributors.

Each instance this paper examines involved more than 100 submissions. Analysis involved an initial reading of the all available texts, which ranged from one to 35 pages, followed by iterative reading of a sample selected on two theoretical grounds. First, the study applied a criterion of salience. Assuming that all respondent voices were legitimate, the analysis took the centrality of actors in the field as an indicator of power and the force of the language to indicate urgency. ${ }^{33}$ This led to identification of texts using stronger rhetoric, the ones more likely, that is, to impress the codes' authors. Second, texts were selected from actors in different parts of the investment chain running from individual savers through banks and brokerages to layers of investment management. ${ }^{34}$ It also examined contributions from peripheral actors, who might offer different or dissonant voices, following the views of Greenwood and Suddaby ${ }^{35}$ that powerful, central actors were likely agents of institutional change, but also of Rao and Giorgi ${ }^{36}$ that peripheral players might effect change through importing ideas from adjacent fields. This detailed scrutiny involved 13 submissions in 1992, 12 in 2003 and 18 documents from six organisations that responded in all three phases of the 2009-10 consultation, leading to iterative reading of other texts.

Initial, theory-led coding led to categorisation according to assumptions from perspectives including agency, stewardship and resource dependency, and by practice-led terms, including boards, directors, investors, advisers, etc. This close reading of the texts led to a second, data-led thematic categorisation, from which the topic of board design emerged as a candidate for closer examination. That issue concerned a structure deeply embedded in practice that seemed to stand little chance of being changed. But because of its political significance it did surface - and resurfaced - seeming to encapsulate the heart of the argument about corporate governance and the role of boards.

\section{Shape of the board}

The unitary board has long been a feature of British corporate governance. Nonetheless, a debate emerged in all three periods: Should the UK retain its unitary boards or move towards a two-tier board favoured by the European Commission and arising in a particular form in Germany? That country's superior economic performance lent cognitive legitimacy ${ }^{37}$ to the 
logic that two-tier boards are a 'better' instrument of corporate governance. The argument for a two-tier approach was that supervisory boards increase independence; the resulting challenge to the power of the executives might prevent the next shock. ${ }^{38}$

The argument against, often subtextual in this debate, concerns Germany's use of Mitbestimmung, or co-determination, a legal mechanism to involve labour unions in determining corporate policy. ${ }^{39}$ The German system is often viewed as the principal contrast to Anglo-American practice. ${ }^{40}$ Unitary boards unite one set of individuals in both a) the boundary-spanning 'service' activities, facilitating access to scarce external resources as emphasised in stewardship theory; and b) the performance-monitoring 'control' activities in agency theory. Dual board systems tend to emphasise the 'control' aspects of the upper or supervisory board.

\section{Board design in the 1992 Cadbury debate}

One reason for the sensitivity on this issue was a longstanding dispute over the European Commission's campaign for a Fifth Company Law Directive. The fight lasted for nearly two decades and was resolved only by a decision not to decide. ${ }^{41}$ The third attempt to pass it, starting in 1988, was opposed strongly by UK business people and the Conservative Party government of Margaret Thatcher. ${ }^{42}$ The Directive sought two politically charged measures: a) the use of two-tier corporate boards, and b) some degree of worker co-determination.

A general election was due by the spring of 1992, however, and the Conservative Party was in turmoil and widely expected to lose. Thatcher had been deposed as prime minister late in 1990 and John Major installed after fractious internal party manoeuvrings. On matters like company law and workers' rights the opposition Labour party might well have taken a different stance.

In a meeting with Sir Adrian Cadbury in September 1991, Marjorie Mowlam, the opposition Labour Party's spokesman on 'City' affairs, made clear her party's intention to legislate unless the Cadbury Committee made substantive changes, though Sir Adrian's notes of the meeting did not mention directly the issue of board design (CAD-01239). Other Labour party members, however, saw value in two-tier boards in submissions to the committee's early deliberations (CAD-01145, CAD-01148) and reflected in related articles in academic journals. ${ }^{43}$

Even after the election in April 1992 had unexpectedly given the Conservatives another term in power, the Liberal Democrats' response to the draft code (CAD-02443) urged two- 
tier boards with employee representation on the lower tier, management board. It also suggested that worker votes be counted alongside shareholder votes at the annual meeting.

That was an extreme position from a peripheral voice, a party with little realistic chance of coming to power soon. But the papers in the Cadbury archive suggest there was some sympathy for the topic within the committee. Jonathan Charkham, the Bank of England adviser attached to the committee, wrote to Cadbury during comment period on the draft assessing a proposal from two contributors to the consultation ${ }^{44}$ to give specific powers to non-executives as 'three-quarters of the way to a two-tier board'. He continued:

There is much logic in what they propose but I have no doubt that it would arouse the fiercest wrath among our critics who can see only too clearly this kind of development coming and are thoroughly scared of real accountability (CAD-01073).

This note shows an important voice arguing that radical change of some sort was needed. Indeed, two years after the code was published, when the committee was conducting its first planned review, Sir Adrian sought legal clarification from the Department of Trade and Industry, an indication he considered the issue important. Nigel Peace, the DTI official who had been secretary to the Cadbury Committee, responded that company law did not prohibit two-tier boards (CAD-01363).

The Cadbury Committee and Sir Adrian personally conducted a wide-ranging series of interviews and received written suggestions from even more people in what was by current practice a rather informal consultation. Shortly after Major's surprise electoral success gave the Conservatives five more years in power, Cadbury published a draft code in May 1992, and his committee undertook a more formal consultation to guide the final code, which was then published in December. Because the draft elicited responses from a wide spectrum of people and organisations affected, the rest of this discussion will concentrate on the more formal, second phase.

In its review of those responses, the Cadbury Committee took special note of three categories of respondents from companies, investors and the accountancy profession, an analytic device followed here. They were summarised for committee members in CAD02255, CAC-02257, CAD-02259, respectively.

Investor reactions: Fund management organisations, in the main, wrote dispassionately, but they expressed concern over steps that might split corporate boards into opposing camps of executives and non-executives. One contributor sees something 'dangerous' in the draft, 
but 'in one or two places'; another says draft makes 'too great a distinction' but adds director interests are only 'somehow opposed'; a comment on the 'different roles but equal responsibilities' accepts division even as it affirms unity; changes 'may bring a distinction' between classes of directors; the report 'undermines' the concept of the unitary board, but only 'to some extent'. (For the fuller context of these remarks, see Table 1).

Place Table 1 about here

An important voice was that of the Association of British Insurers (ABI), whose membership invested in assets amounting to about 25 per cent of the value of the stock market at the time. Many were themselves listed companies, and so had interests straddling the investor/corporation divide. The ABI eschewed emotive language on this issue, with the exception of the ambiguously placed word 'disappointing' in the following passage:

It is perhaps disappointing that there are some who clearly feel that the recommendations undermine the concept of the unitary board, and it might be helpful if the final report emphasised rather more forcefully the support for the unitary board (ABI, CAD-02467).

At first its disappointment seems to be with the 'some' who criticise the draft report, suggested by the proximity of the two words. But the ABI is not in substance disappointed with those who defend the unitary boards. It is disappointed, rather, with the Cadbury Committee for not being more firmly in favour of them, though that point comes clear only after the friendly offer of something 'helpful'. The word order and diction thus seek to accommodate sensitivities to criticism on this point. That this voice needed to be accommodated becomes clear from the committee's own minutes (e.g. CAD-01303).

The Pensions Investment Research Consultants (PIRC), a proxy voting advisory firm representing mainly local authority pension plans, took a stronger line than mainstream fund managers in favour of unitary boards, but with a different aim:

At present many companies insulate some or all of the executive directors from the need to retire and seek election by shareholders. We think this is a serious infringement of shareholder rights and reduces directors' accountability. It also strikes at the heart of the unitary board in which all directors are equally accountable under law $\left(\mathrm{PIRC}^{45}\right)$. 
As these sentences make clear, PIRC is concerned about increasing accountability through elections. It wants to ensure that executive directors face re-election to the board just as often as non-executives. This seeks a different type of board unity than other respondents had in mind, one seeking stronger control over executives, not greater cooperation in the boardroom.

Accountancy reactions: Generally though not entirely, the accountants' contributions on board design objected to the draft and defended the corporate status quo. The first two of the responses in Table 2 ameliorate the critique with phrases like 'tends to imply' and 'understand and accept'. But the more forceful language ('unrealistic', 'inimical') of the third quote, from Ernst \& Young, suggests that feelings were strong. In a handwritten note (CAD02475), Sir Adrian commented that he was 'a bit shaken by the Ernst \& Young demolition job'. ${ }^{46}$

Place Table 2 about here

The Institute of Chartered Accountants in England and Wales (ICAEW), an important professional association whose members included many company chairmen and finance directors, responded to the draft more gently than the accountancy firms themselves:

Many have commented, too, that the report appears to recommend structures and systems which bring about the existence of something close to a two-tier board, in everything but name. The recommendation in favour of a leader for the independent element on the board, where the chairman and chief executive role is combined, and for the use of outside advisers by non-executives are examples in support of this perception. We believe that the truth or otherwise of this assessment should be more fully addressed in the final report and that it would be valuable if a discussion of the comparative merits of unitary and two-tier boards in the UK environment could be included, additionally. We do not, incidentally, favour the appointment of a leader for the non-executive directors (ICAEW, CAD02181).

The mild phrasing of 'it would be valuable' can be read as a quiet taunt to the Cadbury Committee to justify its position; the word 'incidentally' undermines with irony the neutral reference earlier in the passage to the idea of a leader of the non-executives. ${ }^{47}$ 
Corporate reactions: Corporate critiques were unequivocal in advocating a unitary board and opposing European approaches, including two selected for special mention in the summary document circulated to the full committee (CAD-02255):

This risks appearing to encourage a two tier board system, and detracts from the fundamental concept of collective board responsibility. Any change in this approach should be statutory. Assuming the Committee supports the UK's unitary system, it should explicitly state this, and the reasons why it prefers this system (Sir Patrick Sheehy, chairman of British American Tobacco ${ }^{48}$ ).

The whole thrust of the report is to retain the unitary board but to attempt to engraft a two-tier structure on to it. This is not a workable arrangement (The General Electric Co. plc; in the summary but also in CAD-02115).

That summary did not, however, record some of the stronger sentiments received from the corporate side, excluding ones using the emotive words 'danger', 'resist', 'erode', 'poachers' and 'sham', nor an appeal to more rationalist considerations (from Sir Adrian's former family chocolate company) concerning possible loss of 'commercial advantage'. These remarks are summarised in Table 3:

Place Table 3 about here

Perhaps the most forceful statement came not from a submission to the committee, but instead an opinion column published in the Financial Times newspaper, written by Sir Owen Green, chairman of BTR and an emblematic executive of the era. ${ }^{49}$ The article was provocatively titled 'Why Cadbury leaves a bitter taste'. He criticised many aspects of the draft report, including the idea of a 'leader' of the non-executives, and asserted that A more divisive aspect ... is the way it strikes at the heart of the unitary board. It begins by restating the legal position that all directors are equally responsible for the board's decisions. But the committee immediately reveals its view of the real purpose of non-executive directors. They are there to monitor the performance of the board (including themselves?) and that of the chief executive. ${ }^{50}$ 
The phrase 'reveals its real purpose' signals a conspiracy exposed, while 'divisive' warns of adverse consequences and 'strikes at the heart' points metaphorically at murderous intent towards the British way of organising boards. The forcefulness of its sentiment and the impact of its argument is indicated by how Green's column was quoted in the committee's summary of contributions, in notes between committee staff, and by various letters that favourably cited Green's remarks.

Support for two-tier boards: Only a few voices supported the idea of two-tier boards, none with the fervour of the Liberal Democrats. The accountancy firm Arthur Andersen, in a detailed and closely argued analysis, said the committee had paid insufficient attention to what it termed the three roles of boards: supervision, control and management:

We believe the Report should be more forthright with respect to the supervisory function of the board. It should clarify the objectives and procedures that fall within the supervisory function and recommend that in all circumstances, the supervisory role should be led by a specific nonexecutive director.

The Report is predicated on the view that the unitary system is appropriate and the unitary board is itself capable of fulfilling the supervisory function. While we accept that the recommendations in the Report will facilitate supervision, it is disappointing that the Report does not discuss the advantages and disadvantages of alternative forms of governance and encourage experimentation (Arthur Andersen, CAD-02361).

While emphasising 'supervision', the term used for the upper board in a two-tier system, this language falls short of advocacy of European-style boards. The phrase 'predicated on the view' embeds less critique than other expressions of similar content might. But scepticism echoes in the use of 'itself', an otherwise redundant reflexive, as well as in the 'disappointing' choice not to 'encourage experimentation'.

That Arthur Andersen would encourage experiments suggests a position more nearly aligned with concerns of peripheral players about the need for radical change in board design than with actors at the core of the debate or some other intermediaries. ${ }^{51}$ The committee's summary (CAD-02259) quoted the Arthur Andersen view at far greater length than those from other accountancy firms. Sir Adrian made the notation 'experimentation' alongside 
'unitary board' in his handwritten aide memoire concerning possible revisions to the draft (CAD-01267), suggesting he took these comments seriously.

Most of these texts involve assertions of unspecified virtues of unitary boards and warnings of unspecified dangers in two-tier boards. A subtext came to the surface, however, in several contributions. Richard Lloyd, chairman of Vickers, argued that UK board practice was 'more genuinely unitary in its nature' than what happened in the United States or Canada (CAD-01357). J.B.H. Jackson, a self-described 'professional chairman', also worried about importing US practice. Sir Owen Green ${ }^{52}$ was more scathing, attacking the idea of an audit committee entirely composed of non-executives as the 'least meritorious' in the draft, 'notwithstanding the practice in the US'. He then added venom: 'The arrogance of this imported proposal is communicated through the committee's own words' as the draft proposes limits to auditors' responsibility while it 'blandly describes the unlimited liability of the board'.

The foreignness of this element of board design perceived in the Cadbury draft came in complaints from several others about 'continental' or 'German' practices, as well as some oblique and occasionally direct references to European legislation (e.g. Confederation of British Industry, CAD-02349). Ernst \& Young linked the two themes in warning that the 'failure to implement a more effective regulatory regime in the UK now may well deprive the UK of the ability to influence future proposals which, we believe, will emerge from the European Commission for a European Securities and Exchange Commission' (CAD-02447), a contribution noted in the committee summary as well (CAD-02259).

The 'precipitating jolt ${ }^{53}$ the UK system had received from the failures of Polly Peck, BCCI and especially the Maxwell companies ${ }^{54}$ forced a debate over the appropriateness of an aspect of corporate governance that industry had long defended. Opposition was based on economic and political considerations but in particularly on the social aspects of board dynamics. The voices from the twin centres of the debate - corporations and investors - as well as much of the intermediaries argued with varying degrees of force against foreign encroachment in the issue of board design, even though the Cadbury draft report did not explicitly advocate either a German-style supervisory board or an American-style board overwhelmingly populated with outside directors. The strength of opposition is evident in the language of these contributions. Several complained that the changes the draft report sought would demand much effort from companies already well governed, and fail to address the rogues. Green's column in the FT put it this way: 
The report's subliminal message is of the need for total integrity and a healthy objectivity in company affairs. This is strongly to be supported. But the need for a code in addition to existing rules and regulations is doubtful as is its likely effectiveness in reducing the relatively few instances of misbehaviour. ${ }^{55}$

His use of 'subliminal message' evokes symbolically the spectre of manipulative advertising techniques, which had entered public and academic discourse over in previous decades through critiques of technologies to project images interstitially in television signals. ${ }^{56}$ Although Green endorses the message, he opposes the medium of its delivery.

In his briefing to the committee about feedback on the draft, Sir Adrian worried about the tone: 'We are said to be 'long on accountability and short on drive and efficiency' and to take a negative view of governance'; the code risked 'dividing the board'. The first part of these comments highlights the draft's emphasis on control, rather than service, as the function of corporate governance; dividing the board would divide those functions. He then added remarks that imply the code could damage the unity of a board with a weak chairman:

Do we stay with these? Minor changes ... are no problem. I accept that there is a fundamental issue here and that there could come a point when logic would point to a two-tier board. I do not believe we are at that point yet, (although those who advocate distinct legal duties for ned's ${ }^{57}$ would pass it), and that the unity of boards need not be undermined by our proposals, given a competent chairman (Sir Adrian Cadbury, CAD-01265).

The tone of the code changed as a result of the comments and criticism, but these notes from the Cadbury archive suggest the issue was still alive under the surface, even after the final version's support for the unitary board. That Sir Adrian thought 'there could come a point when logic would point to a two-tier board' suggests that the issue was still open, even though hostility had closed it, for now.

\section{Board design in the 2003, post-Higgs debate}

With the collapse of Enron, WorldCom and many other corporations ${ }^{58}$ in the opening years of the millennium, and the implosion of accountants Arthur Andersen, the Labour government in the UK felt something more had to be done. It commissioned a major study of corporate boards, and in particular the role of non-executive directors. 
In the covering letter to his report for the Department of Trade and Industry, Derek Higgs $^{59}$ wrote: 'The brittleness and rigidity of legislation cannot dictate the behaviour, or foster the trust, I believe is fundamental to the effective unitary board and to superior corporate performance'. ${ }^{60}$ Moreover, he expressed the view that the 'architecture' of corporate governance, defined as structure and processes inside companies, 'in itself does not deliver good outcomes'. ${ }^{61}$ Yet his 53 recommendations, summarised at the beginning of the document, dealt overwhelmingly with 'architecture', that is, externally verifiable procedures and structures. These proposals revived concerns about two-tier boards and dominated the consultation the Financial Reporting Council held to translate those recommendations into the text of a new Combined Code.

The passage from Higgs quoted above considers a unitary board to be an implicit good, and in one of the introductory paragraphs he elaborates that view:

Some have argued that the increasing complexity of business life - whether globalisation or fast changing product and capital markets - is such that the whole structure of the board needs to be re-considered. But the majority view, which I share, sees considerable benefits continuing to flow from the unitary approach. ${ }^{62}$

As if to emphasise that point, he later adds:

Increasing the effectiveness of non-executive directors, while preserving the benefits of the unitary board, is a principal objective of the Review.... In contrast, the European system of corporate governance typically separates legal responsibility for running the company between a management and a supervisory board. In the US, the board is composed largely of nonexecutive ('outside') directors with only a few executives. Evidence collected during the Review has not convinced me of the merits of moving away from the unitary board structure in the UK. ${ }^{63}$

This language shows, however, that the debate over board design was not over. The uses of 'unitary' here are defensive: the 'whole structure' needs to be reviewed; that he is 'not convinced' about two-tier boards leaves this issue open in general, just closed for the moment. That he shares the 'majority' view acknowledges the legitimacy of the minority. He has considered other systems ('European' and US) but concludes that the evidence in their favour is not convincing, but its subtext further legitimates those views. Evidence in favour of 
the UK system is not mentioned, an indication that he and the respondents to his consultation and research studies took those advantages as understood, but the word 'unitary' does not appear in Higgs's proposed text of a revised Combined Code. Whether intended or not, taken together these uses and omissions seemed to give respondents reasons to think Higgs had taken a position somewhat short of a ringing endorsement of the unitary boards.

The FRC used the Higgs Review and its proposed code changes as the basis to conduct only a light-touch, 'fatal flaws only' consultation for a new version of the code. The sharply critical reaction it received came as a surprise. ${ }^{64}$ The Association of British Insurers, a mainstream investor voice, saw a 'potential danger to the unitary board' if the code had a 'formal requirement' that non-executive directors meet periodically without the executives or the chairman present (April 2003). ${ }^{65}$ In a literal sense, this is arguing against a case Higgs did not make. Higgs did not require such a move in what is a voluntary code; the text of his draft was that of recommendation: 'should meet regularly as a group without the executives present and at least once a year without the chairman present', ${ }^{66}$ where 'should' also sits underneath the code's 'comply-or-explain' principle.

The Confederation of British Industry (CBI), representing the interests of large corporations, used more forceful language to make a similar point. It expressed 'deep reservations' about provisions that 'concern or affect the chairman', whose role is 'pivotal in the UK's tried and tested unitary board system'. The choice of 'pivotal' here echoes with irony Higgs's own language, ${ }^{67}$ seeking to reverse its inferred intent. The CBI's next sentence elaborates this concern relating it to separate meetings of non-executives, suggesting the provision 'could be misunderstood and could lead to a two-tier board in practice' (16 April 2003). The use of 'could be misunderstood' is an example of language aimed at repairing unintended damage in drafting to maintain the core values of the code. The word might also be seen as a diplomatic way of disrupting a feared change in direction. As in the ABI submission, the value in a unitary board does not receive, or seem to require, explanation or articulation; neither does the 'danger' or 'risk' in a two-tier board.

Sentiment on this point was even stronger among company chairmen. For example, Sir Brian Moffat, chairman of the steelmaker Corus, wrote (20 March 2003) in his capacity as senior independent director of the banking group HSBC not to the FRC, but to its perceived political master: Secretary of State for Trade and Industry Patricia Hewitt. He began with a not-too-subtle attack on what he saw as an attempt to divide the board: He stated his discomfort about writing separately from his fellow directors, lest it be viewed 'undermining the unitary board principle or the Chairman's position'. Such was the 'strength of feeling and 
support in the Board' that he needed to add his voice to that of the HSBC chairman, Sir John Bond, who also wrote to Hewitt on this point (17 March 2003), and later to the FRC (11 April 2003). Moffat wrote under Corus letterhead, making a symbolic further claim of legitimacy in his identity as a company chairman, in addition to his senior non-executive role at HSBC.

\section{Board design in the post-financial crisis debate}

The issue of overall board structure came up again in the debate leading up to the 2010 code. In the initial consultation in early 2009, with its open invitation to raise matters of interest, several mainstream investors and companies alike chose to emphasise the need for a unitary board.

We consider that the unitary board model still represents the most appropriate way forward in the UK context. We also fully support the continued separation of the roles of chairman and chief executive, and an appropriately balanced board (ABI, May 2009, p. 2).

In assessing the merits of these various proposals we have been mindful of the need to ... [p]reserve unitary board structures, with both executive and non-executive directors contributing effectively to the operation of the board (CBI, May 2009, p. 2).

Sentiments like these might have appeared to be boilerplate, language dusted off and reused from a previous consultation paper and not of import, except that the issue was still alive among other actors in the field. Some of them were fringe actors, but others, like the Association of Chartered Certified Accountants (ACCA), were closer to the centre. A professional body with longstanding engagement in corporate governance and many of its accountant-members working in corporations, the ACCA would not normally be seen as peripheral to the field, but its first submission stated:

As a first step, the FRC should consider the implications of introducing as an option a two-tier board structure and should consider the changes to the Code that would need to be articulated (ACCA, May 2009, p. 3).

Its argument was that the financial crisis demonstrated that current arrangements had failed. It laid the blame on the failure of non-executive directors to control managers, and on the custodians of the code for permitting an 'untimely' (p. 2) relaxation in 2008 of the 
constraints on board chairmen and audit committee membership. Boards needed greater independence, not less:

To draw attention to the failure of independent directors is not to say that less reliance should be placed upon them in the future. But consideration needs to be given to addressing the causes of their ineffectiveness.

While two-tier board structures have not always been notably successful, they can contribute to ensuring that the supervisory board directs and oversees, while the management board manages. In practice, much depends on the composition and powers of the two boards in a two-tier structure (ACCA, May 2009, p. 2).

The early mention in (albeit limited) support for two-tier boards through the debate signals that the idea has legitimacy among at least some actors in the field, even though it remains a largely alien concept.

Contributors on the other side, however, affirm the counter-argument but leave it largely unarticulated. The CBI, for example, states that its members, 'including investor members, strongly uphold the UK's unitary board system'; it later states: 'there is also a need to avoid proposals that tend towards two tier boards' (CBI, October 2009). Use of the passive voice here sweeps away any actor, as if the reader - that is, the authors of the code - needed no explanation. The argument was suppressed because its logic was taken for granted. ${ }^{68}$

\section{Discussion}

The issue of board design is emblematic of the purpose of the board. Is this structure for shareholders, for stakeholders, or for the business as a whole? In terms of institutional theory, should the code adopt a logic of shareholder primacy rooted in markets, of representing larger interests rooted in community, or of commerce, rooted in the corporation? Institutional theorists argue that such logics with each other, but the resolution does not always mean victory for one. Instead, logics may develop into a hybrid form ${ }^{69}$ or become sedimented. ${ }^{70}$ This study shows how the contestation of logics was not resolved. Instead, we see opposing logics legitimated through taking part in the debate, or left open through ambiguity. It shows logics neither defeated nor blended, but instead suspended. It also demonstrates how participation seems to develop its own logic, embracing a wide range of opinions without entirely settling the disputes. 


\section{Logics}

Throughout these consultations, actors sought to win their arguments and appeals to these logics, which had been legitimated to a greater or lesser extent in other organisational fields. Even when they made assertions, rather than arguments, the voices in the debate spoke as though their logics were understood and thus taken for granted, as institutional theory suggests. Moreover, some actors attempted to import competing logics from Europe or the US to the UK. That the arguments these logics entail often remained suppressed suggests that other actors already accept, at one level or another, the legitimacy of these solutions.

For example, in 1992 Charkham (CAD-01073) called for 'real accountability' without definition, inviting Cadbury to discover his own meaning, translating from practices elsewhere whether that was hierarchical to shareholders, mutual among directors in the boardroom or both. In 2003, the language used by company chairman in urging changes in the text invited the FRC to interpret their calls either as signs of their stewardship and a logic grounded in the corporation, or as a signal of the legitimacy of shareholder value maximisation based on markets. In 2009-10, the ACCA's call for German-style boards with worker co-determination rests explicitly on a logic embracing shareholder value maximisation. But it imports with it an implicit and unstated acceptance of the legitimacy of co-determination and with it a logic based on the value of a wider community. That the latter is unstated leaves other actors in the field free to translate the call to suit their understanding and see in it heightened monitoring and control.

Over the course of the three periods, many of those supporting unitary boards came from the core actors occupying the central ground in the field. Companies and their collective associations (in particular the CBI) made strongly worded statements but rarely reasoned arguments. Their incumbent position in the centre of the field did not need a defence; rather, the code - a voluntary, not statutory institution - required their assent. Theirs was an assertion that current arrangements were not just appropriate, but superior to the alien concepts of European, German or indeed American practice.

Mainstream institutional investors and their associations (most prominently the ABI) supported this view; many such actors were themselves listed companies and sat on both sides of corporate-investor divide. The advantages of incumbent institutional arrangements were taken for granted, so much so they scarcely needed argumentation. Investors in general did not make their cases on the basis of what agency theory would lead us to think was their interest, that is, to enhance the monitoring and control function through board structure. Their 
logic might reasonably arise from the institutional order of markets, with its focus on the transaction, shareholder primacy and narrow self-interest.

The listed insurance companies that manage equity investments might reasonably be assumed to have faced contesting, even contradictory logics. What we see, however, is something rather different: the absence of conflict on this point, even when the investors were not listed companies or the individuals responding were not in positions to represent the corporate rather than functional (fund management) imperatives. Theirs was in the main a hybrid logic, claiming shareholder primacy but accepting the risk of managerialism in that non-executive directors might be captured by the executives for the sake of strong performance through collegiality and the 'service' function of directors.

The advisers, and especially the accountancy firms, echoed the sentiments of corporations and investors on this point, though not universally and not with the degree of assumption that the incumbent position needed no defence. But the profession was undergoing its own institutional change during this time, as reflected in public discourse, ${ }^{71}$ involving a contest between professional and commercial logics ${ }^{72}$ and perhaps making these actors more sensitive to corporate interests and values.

Those supporting two-tier boards and therefore institutional change came, with important exceptions, from more peripheral positions in the field. Their arguments draw upon a language of high performance, secure investments and long-term orientation, characteristics of German corporate performance. Their texts, mainly tacitly though from the most peripheral actors explicitly, invoke employee rights, stakeholder theory and the associated curbs on behaviour sometimes seen as rapacious Anglo-American capitalism. These are sentiments associated more with the collectivism, with its ideas of shared commitment. That these associations are not always explicit in many of the texts does not mean they are not there. They featured prominently in the discourse in news media at the time. ${ }^{73}$

Those actors straddling the debate were an eclectic bunch, in part peripheral, in part more central to the field. Some suggested novel approaches (e.g. the Liberal Democrats in 1992); others endorsed experimentation (Arthur Andersen in 1992 and, it seems, Sir Adrian Cadbury himself). They were the institutional entrepreneurs, ${ }^{74}$ agitating for change of less specific character to address evident failings in current institutional arrangements. Their arguments embody assumptions or show the willingness to cross boundaries.

How this debate was resolved has had a variety of effects for the relationship between the corporation and investors and on the relationships across the field, in shaping a language of corporate governance that gains acceptance and builds a community. But at the same time, set 
against the changing context, the debate raises questions about the code's affirmation a set of mainstream actors increasingly less central to the investment field.

These expressions of ambiguity and the suppression of arguments, assumed and taken for granted, suggest that actors have and want room to interpret the logic as they see fit and blend it with others as circumstances require. ${ }^{75}$ These half-made arguments, with their scope for reinterpretation by other actors, create room for accommodation with other actors, a way to set conflict to the side for the sake of agreement, in the knowledge, first, that the code will be revisited before too long, and second, that if corporations do not comply they will still have the option to explain.

\section{Actors and their relationships}

The detail of the debate analysed above shows that through this period, actors in the centre of the field - the traditional UK corporations and mainstream UK investors - lost more arguments than they won on measures like the prominence of non-executives and the use of committees that might introduce a two-tier board through the back door. In 2003 they lost arguments they had won in 1992, such as the question of whether there should be a leader of the non-executives. But they demanded and retained affirmation of the value of a unitary board. Indeed, the change in tone in 2010 reinforced the ethos of a unitary board even as it left in place the structures weighing against it.

Peripheral actors seeking institutional change won the substance of theirs, if not in the form they might have liked. Those urging experimentation in board design lost in 1992 and 2003 but won in 2010, assuming companies embraced the spirit rather than the letter of the code that Nordberg and McNulty document. ${ }^{76}$ They won concessions in the code, through measures to increase board independence that mimicked the two-tier board and therefore created the check the Cadbury Code sought on the 'unfettered power' of executives in corporate decision-making. These outcomes concentrated influence in the centre of the field, but now more in the hands of mainstream institutional investors, and less with companies and their managers. Perversely the shift in discretion limited the outcomes of employee empowerment and stakeholder rights those more peripheral actors had sought. But by having the debate, the process created an avenue for continued dialogue.

That the debate has not concluded points to research opportunities tracking whether power consolidates in the centre of embraces more of the elements that the more peripheral actors wanted to see. In particular, the calls for experimentation in board design that Sir 
Adrian Cadbury acknowledged may be worth monitoring, in view of the failure of the mainstream solutions tried so far to prevent catastrophic corporate failures.

\section{Acceptance of legitimacy of disparate voices}

The debate, and the process that leads to continuing dialogue, gave legitimacy to a wide variety of actors and interests other than those in the centre of the field and with the cosy relationships of old in the City. It also provided a language in which the debate could be framed. One consequence was, therefore, the creation of a community of corporate governance made up of individuals who participated in the debate, even at several steps removed, and learned its language.

Here further research might explore the sociology of the field. Some of the actors whose voices we have heard are now departed - individuals who have died or organisations that have been acquired or collapsed. But the continuation of the debate has brought others of similar character into the conversation. Is the sense of a community a strong one that gives a trajectory to the debate? Or are the interests of actors so strong that the institution of the code will grow rigid and impervious to change?

\section{Fit with the changing context}

The voices heard in the debates in 1991-92, 2003 and 2009-10 were remarkably similar and in some cases identical voices. Missing from the later debates were the new actors on the scene, notably the sovereign wealth funds, hedge funds and the large mainstream institutional investors from the United States and other countries, which now collectively hold the majority of UK shares. Their influence on corporate decision-making is considerable, as shareholder activism has gained force from the affirmation of the special position of institutional investors as guardians of the corporate governance in Cadbury and since. The financial crisis gave new impetus to shareholder activism in many countries, ${ }^{77}$ which may have the consequence of focusing attention of corporate executives on shareholder interest to the exclusion of the wider range of actors that the debate over board design gave voice.

Respondents to the Cadbury Committee and again in 2003 included representatives of many of the largest corporations. By 2010, however, the make-up of the London Stock Exchange listing included many foreign corporations, which sought its liquidity and the legitimacy association with UK corporate governance. Yet these voices played little role in the 2010 debate. 
Moreover, formal institutional development in law and regulation may diminish the hold of a voluntary code of conduct like the UK Corporate Governance Code, in particular over the minds of the more peripheral actors. The absence of those voices - of those on the periphery and those in the new gravitational centre of the field - from future debates would throw the legitimacy of the code, its prescriptions and its flexibility, into doubt.

\section{Conclusions}

This study has examined how the UK code of corporate governance was created and how it developed over time. Its development has not only influenced the practice of corporations and investors, it has informed institution-building in countries well beyond the UK. By looking in detail at one issue, the design of the board, it gives insights about how codes of conduct emerge and institutionalise without stamping out alternative understandings that might hold value in other ways and perhaps at another time. Voices not acknowledged in the code are not extinguished; indeed they are legitimated by the process of codification, which facilitates their broad acceptance and helps the code to become institutionalised.

This study suggests that by engaging in the process of code-writing, actors may be creating a new logic, arising more from a collective stance rather than the narrower interests and a new community. It thus affirms the view in Puxty et al. ${ }^{78}$ that the changes in structure of social relations happen at the interaction of domains, where new principles and logics develop. It also suggests that those principles and logics can gain legitimacy without full acceptance if the values they embody include openness and thoughtfulness.

But the study also raises questions about whether such processes of semi-formal institutions like the UK code can keep pace with a rapidly changing market context and the attempts by authorities to adapt formal institutions in response. Even when the processes are open and their outcomes flexible, they remain institutionalised. Apart from the three responses to crises examined in this study, revision to the UK code has become a ritualised affair, with layers of new principles and guidelines added to those already in place. This is a field in much flux and one that needs continuing attention from scholars, practitioners and policy-makers alike.

\section{Postscript}

In June 2016, after the surprise vote in a referendum seeking Britain's withdrawal from the European Union, a new, unelected prime minister came to power with a promise to shake 
up UK corporate governance and introduce worker representation on boards of directors. ${ }^{79}$ In so doing Theresa May curiously revived a 'continental' idea just as the government was leaving the continent behind. While the government's language shifted ahead of the next big consultation, announced that December, it was clear that old ideas have not been discarded and that their legitimacy for important constituencies remained intact. Indeed, the idea resurfaced in the Conservative Party's manifesto for the snap general election in June 2017. The process of institutionalisation of corporate governance in UK had left discarded logics suspended, not blended, as well as leaving avenues open for other logics to gain a place in the fresh contest. Time would tell if perhaps a new logic would appear, embracing the changed context and the new actors. 


\section{Appendix 1 - Consultation processes, 1992, 2003, 2009-10}

After wide-ranging interviews and exchanges of letters, Sir Adrian Cadbury and his committee wrote a draft code mid-1992 and invited formal responses to it. The archive records several hundred communications before and then again after the May 1992 draft code. Following the Higgs Review in January 2003, the FRC held a 'fatal flaws only' review of the draft code that Higgs had proposed. The result was a torrent of protest that the FRC chairman Sir Bryan Nicholson ${ }^{80}$ later recalled as 'media noise level and the hostility ... by company Chairmen'. In this consultation, the FRC heard from about 180 organisations and individuals, mainly on the corporate side, though mainstream investors and their associations responded as well. In 2009-10 came a three-stage consultation, which sought views on the code itself and also on whether the lessons learned from a separate study of governance in the financial services sector might have broader application in industry. The FRC received more than a hundred responses in each phase, with new voices appeared in the latter two stages. The FRC chairman, Sir Christopher Hogg, a veteran company executive and chairman who had served as adviser to Cadbury in 1992, then took all the contributions and with the help of FRC staff fashioned a new code with a new tone. ${ }^{81}$ 
Table 1 - Responses of investors to Cadbury draft on board design

\begin{tabular}{|l|l|}
\hline Source & Comment \\
\hline $\begin{array}{l}\text { Postel Investment } \\
\text { Management } \\
\text { (CAD-02195) }\end{array}$ & $\begin{array}{l}\text { [. the report in one or two places comes dangerously close to } \\
\text { undermining the concept of the unitary board. }\end{array}$ \\
\hline $\begin{array}{l}\text { Institutional Fund } \\
\text { Managers }\end{array}$ & $\begin{array}{l}\text { The Report draws too great a distinction between the responsibilities } \\
\text { of executive and non-executive directors and could be taken to imply } \\
\text { that their interests are somehow opposed. We believe that the Code } \\
\text { should place greater emphasis on the need for each director to } \\
\text { recognise his responsibility for corporate governance, however the } \\
\text { Board is constituted, and for the Board as a whole to recognise its } \\
\text { responsibility and that of each of its members. }\end{array}$ \\
\hline $\begin{array}{l}\text { Legal \& General } \\
\text { (CAD-02353) }\end{array}$ & $\begin{array}{l}\text { We are however concerned that Board balance between executive } \\
\text { and non executive should not be translated into a separation into } \\
\text { supervisory and non supervisory functions with the two-tier } \\
\text { implication that that would suggest. We see the directors as having } \\
\text { different roles but equal responsibilities, with all of them ultimately } \\
\text { being responsible to those who elect them - the shareholders. }\end{array}$ \\
\hline $\begin{array}{l}\text { British Rail Pension } \\
\text { Fund (CAD-02453) }\end{array}$ & $\begin{array}{l}\text { The additional duties proposed for non-executive directors (together } \\
\text { with the previously mentioned head of non-executives) may bring a } \\
\text { division into the board if non-executives are to take on a more } \\
\text { supervisory role. It is probably more important for companies to } \\
\text { describe their internal monitoring procedures and formally report on } \\
\text { their operation in the annual report than for a general duty to monitor } \\
\text { being ascribed to particular members of a unitary board. }\end{array}$ \\
\hline $\begin{array}{l}\text { National Association } \\
\text { of Pension Funds } \\
\text { (CAD-02449) }\end{array}$ & $\begin{array}{l}\text { So far as reporting to shareholders is concerned, your suggestion that } \\
\text { the chairman of the remuneration committee be responsible for } \\
\text { answering questions at the Annual General Meeting may well } \\
\text { undermine, to some extent, the concept of the unitary board. }\end{array}$ \\
\hline
\end{tabular}


Table 2 - Accountants' responses to Cadbury draft on board design

\begin{tabular}{|l|l|}
\hline Source & Comment \\
\hline $\begin{array}{l}\text { Cybrand } \\
\text { (CAD- } \\
02363)\end{array}$ & $\begin{array}{l}\text {. the language of the draft report as it stands tends to imply a sharper } \\
\text { division between the roles of non-executives and executives than the } \\
\text { Committee probably intends. We do not believe there is a satisfactory half } \\
\text { way house between the two tier board and the collegiate board. }\end{array}$ \\
\hline $\begin{array}{l}\text { Pannell Kerr } \\
\text { (CAD- }\end{array}$ & $\begin{array}{l}\text { We understand and accept that there is a need for a division of } \\
\text { responsibilities within a board and that no large listed company should be } \\
\text { capable of being dominated by one individual but we are concerned about the } \\
\text { apparent belief that within a board there should be two leaders. We feel very } \\
\text { strongly that the duty of the Board (within the constraints of the law) as a } \\
\text { whole is to create wealth for the investors. The Board has, therefore, to work } \\
\text { as a team, and not to be put in a position where half the Board's main } \\
\text { purpose appears to be to police the activities of the other half. We are } \\
\text { concerned that whilst the report makes this point ... the overall impression of } \\
\text { the report, because it deals with controls is one where the vision of the non- } \\
\text { executive is that he is there to dismiss the chief executive should this prove } \\
\text { necessary rather than provide positive input to the future direction and } \\
\text { success of the company. We believe non executive directors have an } \\
\text { important role to play in bringing their broader experience to bear on the } \\
\text { board's discussions. }\end{array}$ \\
\hline $\begin{array}{l}\text { We acknowledge the important contribution which non-executive directors } \\
\text { can and should make in this direction but believe that the Committee's } \\
\text { expectations of non-executive directors are unrealistic. We also believe that } \\
\text { certain aspects of the role which the Committee proposes for non-executive } \\
\text { directors are inimical to the concept of the unitary board... The Committee's } \\
\text { proposals would create a two-tier board within the legal structure of a unitary } \\
\text { board. We do not regard this as tenable. }\end{array}$ \\
$02447)$
\end{tabular}


Table 3 - Corporate reaction to Cadbury draft on board design

\begin{tabular}{|c|c|}
\hline Source & Comment \\
\hline $\begin{array}{l}\text { Lord Tombs, chairman, } \\
\text { Rolls-Royce plc (CAD- } \\
\text { 02377). }\end{array}$ & $\begin{array}{l}\text { In our view distinctions between the responsibilities of } \\
\text { executive and non-executive directors, save in relation to } \\
\text { remuneration, are both divisive and, for example, in the } \\
\text { case of decision making through a two tier board, a sham. }\end{array}$ \\
\hline $\begin{array}{l}\text { Confederation of } \\
\text { British Industry (CAD- } \\
\text { 02349). }\end{array}$ & $\begin{array}{l}\text { In that setting it is for the board to distribute functions to } \\
\text { its members; attempts to reserve tasks as a rule to one } \\
\text { class of directors will create the danger of opening the } \\
\text { way to a two-tier system.... We oppose the words } \\
\text { 'monitor the executive management' as imparting a } \\
\text { supervisory role inappropriate to a unitary board. }\end{array}$ \\
\hline $\begin{array}{l}\text { Institute of Directors } \\
\text { (CAD-02423) }\end{array}$ & $\begin{array}{l}\text { Whilst the presence of such a system of checks and } \\
\text { balances is an integral element of effective corporate } \\
\text { governance, it should not way be allowed to erode the } \\
\text { principle of a unitary board. }\end{array}$ \\
\hline $\begin{array}{l}\text { J.F. Mahony, Group } \\
\text { Finance Director and } \\
\text { Vice-Chairman, } \\
\text { Ladbroke Group } \\
\text { (CAD-02441) }\end{array}$ & $\begin{array}{l}\text { I would resist any movement towards a two-tier system. I } \\
\text { believe that paragraph } 4.3 \text { is unhelpful as the role of the } \\
\text { non-executive directors outlined in it appears to conflict } \\
\text { with the principle of a unitary board in so far as it implies } \\
\text { that the purpose of the non-executive directors is to } \\
\text { monitor the performance of the board. In this context, the } \\
\text { non-executive directors must be monitoring the } \\
\text { performance of the executive members of the board, not } \\
\text { the board as a whole. The draft report should be amended } \\
\text { to make it clear that the principle of a unitary board is } \\
\text { upheld in all respects. }\end{array}$ \\
\hline $\begin{array}{l}\text { Alick Rankin, } \\
\text { Chairman, Scottish \& } \\
\text { Newcastle (CAD- } \\
\text { 02455) }\end{array}$ & $\begin{array}{l}\text { The code, as proposed, appears to identify non-executive } \\
\text { directors as 'the gamekeepers' and executives as 'the } \\
\text { poachers'. Clearly, this must be quite wrong. It is both } \\
\text { divisive and intrusive and damaging to the positive } \\
\text { partnership spirit essential in a unitary board. Non- } \\
\text { executives have a strong requirement to encourage, to } \\
\text { support and to enthuse - this concept is lacking and } \\
\text { severely threatened by the proposals. }\end{array}$ \\
\hline $\begin{array}{l}\text { Peter Jinks, Company } \\
\text { Secretary, Cadbury- } \\
\text { Schweppes (CAD- } \\
\text { 02385) }\end{array}$ & $\begin{array}{l}\text { The emphasis on more involvement and accountability of } \\
\text { Non-Executive Directors emerging from Corporate } \\
\text { Governance must not result in or encourage two tier } \\
\text { Boards, which would be of considerable commercial } \\
\text { disadvantage to the company and its investors. }\end{array}$ \\
\hline
\end{tabular}




\footnotetext{
${ }^{1}$ Nordberg and McNulty, "Creating better boards through codification: Possibilities and
} limitations in UK corporate governance, 1992-2010."; Spira and Slinn, The Cadbury Committee: A History.

${ }^{2}$ Bruni and Llewellyn, The failure of Northern Rock: A multi-dimensional case study. FCA and PRA, The Failure of HBOS plc, FSA, The Failure of the Royal Bank of Scotland plc. ${ }^{3}$ Ocasio, "Attention to Attention."

${ }^{4}$ Cadbury, The Financial Aspects of Corporate Governance. The work is made up of the code (two pages of principles) and a report providing justifications for its recommendations.

${ }^{5}$ Battilana and Dorado, "Building Sustainable Hybrid Organizations: The Case of Commercial Microfinance Organizations, Glynn and Lounsbury, "From the Critics' Corner: Logic Blending, Discursive Change and Authenticity in a Cultural Production System." ${ }^{6}$ Nordberg and McNulty, "Creating better boards through codification: Possibilities and limitations in UK corporate governance, 1992-2010."

${ }^{7}$ This layering can mean that logics persist even when defeated, leaving conflicting practices in place. See Cooper et al., "Sedimentation and Transformation in Organizational Change: The Case of Canadian Law Firms, Soin and Huber, "The Sedimentation of an Institution: Changing Governance in U.K. Financial Services."

${ }^{8}$ Spira and Slinn, The Cadbury Committee: A History.

${ }^{9}$ DiMaggio and Powell, "The Iron Cage Revisited: Institutional Isomorphism and Collective Rationality in Organizational Fields."

${ }^{10}$ See Marquis and Lounsbury, "Vive la résistance: Competing logics and the consolidation of U.S. community banking." See p. 799.

${ }^{11}$ Thornton et al., The Institutional Logics Perspective: A New Approach to Culture, Structure, and Process. See p. 2.

${ }^{12}$ Green, "A rhetorical theory of diffusion."

${ }^{13}$ Puxty et al., "Modes of regulation in advanced capitalism: Locating accountancy in four countries."

${ }^{14}$ Lok, "Institutional Logics as Identity Projects, Zajac and Westphal, "The Social

Construction of Market Value: Institutionalization and Learning Perspectives on Stock Market Reactions."

${ }^{15}$ Aguilera and Cuervo-Cazurra, "Codes of Good Governance."

${ }^{16}$ E.g. Cromme Commission, German Corporate Governance Code. 
${ }^{17}$ NYSE, Final NYSE Corporate Governance Rules. Nasdaq, Summary of NASDAQ Corporate Governance Proposals.

${ }^{18}$ The Financial Reporting Council alludes to this small world in the introduction to its guide to UK corporate governance. See FRC, The UK Approach to Corporate Governance.

${ }^{19}$ This phrase is the official title of the Cadbury Report; Sir Adrian Cadbury moved beyond the original scope of the inquiry to dwell on organisational recommendations for corporations and their relationship with shareholders.

${ }^{20}$ The feeble Conservative government led by John Major was widely expected to lose the election that had to take place by May 1992. The party was itself deeply divided, over membership in the European Community and by the defenestration of Margaret Thatcher as party leader and as prime minister from mid-1979 to November 1990.

${ }^{21}$ For a discussion of this less formal type of institutional theorising see: Suchman,

"Managing legitimacy: strategic and institutional approaches."

${ }^{22}$ Aguilera et al., "Sovereign wealth funds: A strategic governance view."

${ }^{23}$ ONS, Ownership of UK Quoted Shares, 2012.

${ }^{24}$ Katelouzou, "Myths and Realities of Hedge Fund Activism: Some Empirical Evidence."

${ }^{25}$ McPhilemy, "Formal Rules versus Informal Relationships: Prudential Banking Supervision at the FSA Before the Crash."

${ }^{26}$ This interpretation is disputed by some who read Section 172 of the Act from a stakeholder perspective. But the language is quite different from Dutch law, for example, with its explicit duties to employees, customers and suppliers. See also Keay, The Enlightened Shareholder Value Principle and Corporate Governance.

${ }^{27}$ Nordberg and McNulty, "Creating better boards through codification: Possibilities and limitations in UK corporate governance, 1992-2010."

${ }^{28}$ Cadbury, The Financial Aspects of Corporate Governance.

${ }^{29}$ FRC, Combined Code on Corporate Governance.

30 ---, The UK Corporate Governance Code.

${ }^{31}$ Walker, A review of corporate governance in UK banks and other financial industry entities: Final recommendations.

${ }^{32}$ Green, Personal View: Why Cadbury leaves a bitter taste.

${ }^{33}$ Mitchell et al., "Toward a theory of stakeholder identification and salience: Defining the principle of who and what really counts." 
${ }^{34}$ The concept of an investment chain or investment supply chain is a market shorthand for the layers of intermediaries lying between the originators of savings and, for equity markets, the company in which the funds are ultimately invested. In the aftermath of the 2007-09 financial crisis the length of the investment chain was the object of a government-mandated critique of market short-termism. See Kay, The Kay review of UK equity markets and longterm decision making - Final report.

${ }^{35}$ Greenwood and Suddaby, "Institutional entrepreneurship in mature fields: The Big Five accounting firms."

${ }^{36}$ Rao and Giorgi, "Code Breaking: How Entrepreneurs Exploit Cultural Logics to Generate Institutional Change."

${ }^{37}$ Greenwood et al., "Theorizing change: The role of professional associations in the transformation of institutionalized fields."

${ }^{38}$ The failures of Herstatt Bank in the 1970s, the construction equipment maker IBH in the 1980s and the metals trading company Metallgesellschaft in the 1990s find surprising little resonance in discussions of corporate governance outside Germany. The first bank failures in the financial crisis of 2007-09 were in Germany: Industrie-Kredit Bank and Sachsen LB, both of which invested heavily in US subprime mortgage securities.

${ }^{39}$ In contrast to the Dutch or Swiss practice, half the members of German supervisory boards are drawn from the workforce, a feature of German law since the time Bismarck. See Fear "German Capitalism.".

${ }^{40}$ See Charkham, Keeping Better Company: Corporate governance ten years on, ---, Keeping Good Company: A study of corporate governance in five countries. Also, Goergen, "Corporate stakeholders and trust."

${ }^{41}$ Winter, Report of the high level group of company law experts on a modern regulatory framework for company law in Europe.

${ }^{42}$ Montgomery, "European Community's Draft Fifth Directive: British Resistance and Community Procedures."

${ }^{43}$ Cousins and Sikka, "Accounting for Change: Facilitating Power and Accountability, Mitchell and Sikka, "Accounting For Change: The Institutions of Accountancy,"---. ${ }^{44}$ The 'Merrett-Sykes paper he refers to is not recorded in the Cadbury Archive, although Alan Sykes, managing director of Consolidated Gold Fields, mentions it in a separate comment on the draft report (CAD-02141). Anthony Merrett, a London Business School 
professor, and Sykes made a second proposal concerning the accountability of auditors (CAD-02185).

${ }^{45}$ The PIRC submission itself is not recorded in the Cadbury Archive, but the firm provided a late draft of the document for this study, which is quoted here. The Cadbury Committee's summary of investor reactions cites long passages from the PIRC submission on other matters but only notes that PIRC supported a unitary board. It does not quote this passage. ${ }^{46}$ The comment referred to the E\&Y submission in general, which was also critical of the report in other matters.

${ }^{47}$ For a wry look at the use of euphemisms in British speech, including 'incidentally', see Economist, Euphemisms: Making Murder Acceptable.

${ }^{48}$ Sheehy's submission itself is not recorded in the Cadbury Archive; this excerpt comes from the committee's summary CAD-02255.

${ }^{49}$ The respect Green achieved is made clear in a recent case study of his long career at BTR. See Kerr, "Transformation at BTR."

${ }^{50}$ Green, Personal View: Why Cadbury leaves a bitter taste.

${ }^{51}$ Arthur Andersen was at the time a highly respected voice in the accountancy profession. Its disintegration a decade later after the collapse of clients Enron, WorldCom and others may be traced in part to what we might term governance 'experimentation', but not perhaps experiments in enhanced supervision.

${ }^{52}$ Green, Personal View: Why Cadbury leaves a bitter taste.

${ }^{53}$ The phase is used in institutional theory to discuss how contextual change can initiate institutional reform; see Greenwood et al., "Theorizing change: The role of professional associations in the transformation of institutionalized fields."

${ }^{54}$ Sir Adrian notes to the committee considering the responses to the draft (CAD-01265) speak of recommendations needing to pass the 'Maxwell test', so called because Robert Maxwell would have signed off his companies as having complied with the code, and neither his directors nor auditors would have challenged that view.

${ }^{55}$ Green, Personal View: Why Cadbury leaves a bitter taste.

${ }^{56}$ Consider Zanot et al., "Public perceptions of subliminal advertising." Also, Beatty and Hawkins, "Subliminal Stimulation: Some New Data and Interpretation,"---. ${ }^{57}$ ned's (lower case) is Sir Adrian's personal short notation for non-executive directors. 
${ }^{58}$ The UK experienced no corporate failures of any great magnitude, despite the tumult in the US and major failures in continental Europe and Asia, and the collapse of Germany's Neuer Markt, a stock market for new economy companies.

${ }^{59}$ Higgs received a knighthood after his review was transposed into the Combined Code of 2003.

${ }^{60}$ Higgs, Review of the Role and Effectiveness of Non-Executive Directors.

${ }^{61}$ Ibid., at paragraph 1.3 .

${ }^{62}$ Ibid., at paragraph 1.7.

${ }^{63}$ Ibid., at paragraphs 4.2, 4.3 .

${ }^{64}$ Nicholson, "The role of the regulator."

${ }^{65}$ Owing to the circumstances concerning the source material, references to submissions to the post-Higgs consultation are given only to the respondent and the date of the response. ${ }^{66}$ Provision A.1.5 of Higgs, Review of the Role and Effectiveness of Non-Executive

\section{Directors.}

${ }^{67}$ Ibid., at paragraph 5.1

${ }^{68}$ For an account of the role of rhetoric in institutionalisation, see Green et al., "Suspended in self-spun webs of significance: A rhetorical model of institutionalization and institutionally embedded agency."

${ }^{69}$ Ebrahim et al., "The governance of social enterprises: Mission drift and accountability challenges in hybrid organizations."

${ }^{70}$ Soin and Huber, "The Sedimentation of an Institution: Changing Governance in U.K. Financial Services."

${ }^{71}$ Glynn and Lounsbury, "From the Critics' Corner: Logic Blending, Discursive Change and Authenticity in a Cultural Production System."

${ }^{72}$ Hinings et al., "Change in an autonomous professional organization,"---, Suddaby and Greenwood, "Rhetorical Strategies of Legitimacy."

${ }^{73}$ In 2009, for example, The Financial Times newspaper produced a long series of articles from high profile contributors, later issued as a monograph, 'The Future of Capitalism' (May 12, 2009).

${ }^{74}$ The term for actors agitating to change institutional arrangements was introduced in DiMaggio, "Interest and agency in institutional theory."

${ }^{75}$ Zattoni and Cuomo, "Why Adopt Codes of Good Governance? A Comparison of Institutional and Efficiency Perspectives." 
${ }^{76}$ Nordberg and McNulty, "Creating better boards through codification: Possibilities and limitations in UK corporate governance, 1992-2010."

${ }^{77}$ Becht et al., The Returns to Hedge Fund Activism: An International Study, Cheffins and Armour, "The Past, Present, and Future of Shareholder Activism by Hedge Funds, Goranova and Ryan, "Shareholder Activism: A Multidisciplinary Review, McNulty and Nordberg, "Ownership, Activism and Engagement: Institutional Investors as Active Owners."

${ }^{78}$ Puxty et al., "Modes of regulation in advanced capitalism: Locating accountancy in four countries."

${ }^{79}$ O'Connor and Brunsden, Businesses wary of Theresa May's board reforms.

${ }^{80}$ Nicholson, "The role of the regulator."

${ }^{81}$ Personal communication with the author.

${ }^{82}$ Postel was reincorporated as Hermes Investment Management in 1995. 


\section{References}

Aguilera, R.V. and A. Cuervo-Cazurra, "Codes of Good Governance." Corporate Governance: An International Review 17, no. 3 (2009): 376-87.

Aguilera, R.V., J. Capapé, and J. Santiso, "Sovereign wealth funds: A strategic governance view." Academy of Management Perspectives Online First (2015), doi:10.5465/amp.2013.0055.

Battilana, J. and S. Dorado, "Building Sustainable Hybrid Organizations: The Case of Commercial Microfinance Organizations." Academy of Management Journal 53, no. 6 (2010): 1419-40.

Beatty, S.E. and D.I. Hawkins, "Subliminal Stimulation: Some New Data and Interpretation." Journal of Advertising 18, no. 3 (1989): 4-8.

Becht, M., J. Franks, J. Grant, and H.F. Wagner, "The Returns to Hedge Fund Activism: An International Study," SSRN eLibrary. Accessed 21 May, 2015. http://dx/doi.org/10.2139/ssrn.2376271.

Bruni, F. and D.T. Llewellyn, eds., The failure of Northern Rock: A multi-dimensional case study (Vienna: SUERF - The European Money and Finance Forum, 2009), http://www.suerf.org/download/studies/study20091.pdf.

Cadbury, A., "The Financial Aspects of Corporate Governance," Gee Publishing. Accessed 1 September, 2015. http://www.ecgi.org/codes/documents/cadbury.pdf.

Carnegie, G.D. and C.J. Napier, "Traditional accountants and business professionals: Portraying the accounting profession after Enron." Accounting, Organizations and Society 35, no. 3 (2010): 360-76, doi:10.1016/j.aos.2009.09.002.

Charkham, J. Keeping Better Company: Corporate governance ten years on. Oxford: Oxford University Press, 2005.

Charkham, J. Keeping Good Company: A study of corporate governance in five countries. Oxford: Oxford University Press, 1994.

Cheffins, B.R. and J. Armour, "The Past, Present, and Future of Shareholder Activism by Hedge Funds." Journal of Corporation Law 37, no. 1 (2011): 51-103.

Cooper, D.J., B. Hinings, R. Greenwood, and J.L. Brown, "Sedimentation and Transformation in Organizational Change: The Case of Canadian Law Firms." Organization Studies 17, no. 4 (1996): 623-47.

Cousins, J. and P. Sikka, "Accounting for Change: Facilitating Power and Accountability." Critical Perspectives on Accounting 4, no. 1 (1993): 53-72.

Cromme Commission, "German Corporate Governance Code," Government Commission of the German Corporate Governance Code. Accessed 20 June, 2007. http://www.corporate-governance-code.de.

DiMaggio, P.J., "Interest and agency in institutional theory," in Institutional patterns and culture, edited by Zucker, L.G., 3-32. Cambridge, MA: Ballinger, 1988.

DiMaggio, P.J., and W.W. Powell, "The Iron Cage Revisited: Institutional Isomorphism and Collective Rationality in Organizational Fields." American Sociological Review 48, no. 2 (1983): 147-60. 
Ebrahim, A., J. Battilana, and J. Mair. "The Governance of Social Enterprises: Mission Drift and Accountability Challenges in Hybrid Organizations." Research in Organizational Behavior 34 (2014): 81-100.

Economist, "Euphemisms: Making Murder Acceptable," Economist Newspaper Ltd. Accessed 27 December, 2011. http://www.economist.com/node/21541767.

FCA and PRA, "The Failure of HBOS plc," Bank of England. Accessed 19 November, 2015. http://www.bankofengland.co.uk/pra/Documents/publications/reports/hbos.pdf.

Fear, J., "German Capitalism," Chap. 5, In Creating Modern Capitalism: How entrepreneurs, companies, and countries triumphed in three industrial revolutions, edited by McCraw, T.K., 133-82. Cambridge, MA: Harvard University Press, 1997.

Forbes, D.P. and F.J. Milliken, "Cognition and corporate governance: Understanding boards of directors as strategic decision-making groups." Academy of Management Review 24, no. 3 (1999): 489-505, doi:10.5465/AMR.1999.2202133.

FRC, "Combined Code on Corporate Governance," UK Financial Reporting Council. Accessed 20 June, 2006.

http://www.frc.org.uk/documents/pagemanager/frc/Web\%20Optimised\%20Combined\% 20Code\%203rd\%20proof.pdf.

FRC, "The UK Approach to Corporate Governance," UK Financial Reporting Council. Accessed 15 August, 2012. http://www.frc.org.uk/getattachment/1db9539d-9176-454691ee-828b7fd087a8/The-UK-Approach-to-Corporate-Governance.aspx.

FRC, "The UK Corporate Governance Code," UK Financial Reporting Council. Accessed 29 May, 2010.

http://www.frc.org.uk/documents/pagemanager/Corporate_Governance/UK\%20Corp\%2 0Gov\%20Code\%20June\%202010.pdf.

FSA, "The Failure of the Royal Bank of Scotland plc," UK Financial Services Authority. Accessed 19 November, 2015. http://www.fsa.gov.uk/pubs/other/rbs.pdf.

Glynn, M.A. and M. Lounsbury, "From the Critics' Corner: Logic Blending, Discursive Change and Authenticity in a Cultural Production System." Journal of Management Studies 42, no. 5 (2005): 1031-55.

Goranova, M. and L.V. Ryan, "Shareholder Activism: A Multidisciplinary Review." Journal of Management 40, no. 5 (2014): 1230-68, doi:10.1177/0149206313515519.

Green, O., "Personal View: Why Cadbury leaves a bitter taste," Chap., In Financial Times, 19. London: Financial Times Ltd., 1992.

Green, S.E., Jr., "A rhetorical theory of diffusion." Academy of Management Review 29, no. 4 (2004): 653-69.

Green, S.E., Jr., Y. Li, and N. Nohria, "Suspended in self-spun webs of significance: A rhetorical model of institutionalization and institutionally embedded agency." Academy of Management Journal 52, no. 1 (2009): 11-36.

Greenwood, R. and R. Suddaby, "Institutional entrepreneurship in mature fields: The Big Five accounting firms." Academy of Management Journal 49, no. 1 (2006): 27-48.

Greenwood, R., R. Suddaby, and C.R. Hinings, "Theorizing change: The role of professional associations in the transformation of institutionalized fields." Academy of Management Journal 45, no. 1 (2002): 58-80. 
Higgs, D., "Review of the Role and Effectiveness of Non-Executive Directors," UK Department of Trade and Industry. Accessed 15 October, 2006. http://www.ecgi.org/codes/documents/higgsreport.pdf.

Hinings, C.R., J.L. Brown, and R. Greenwood, "Change in an autonomous professional organization." Journal of Management Studies 28, no. 4 (1991): 375-93.

Katelouzou, D., "Myths and Realities of Hedge Fund Activism: Some Empirical Evidence." Virginia Law \& Business Review 7, no. 3 (2013): 459-511.

Kay, J. "The Kay Review of UK Equity Markets and Long-Term Decision Making - Final Report." UK Department of Business, Innovation and Skills, (2012). Accessed 23 July 2012. http://www.bis.gov.uk/assets/biscore/business-law/docs/k/12-917-kay-review-ofequity-markets-final-report.pdf.

Keay, A. The Enlightened Shareholder Value Principle and Corporate Governance. Oxford: Routledge, 2013.

Lok, J., "Institutional Logics as Identity Projects." Academy of Management Journal 53, no. 6 (2010): 1305-35, doi:10.5465/AMJ.2010.57317866.

Marquis, C. and M. Lounsbury, "Vive la résistance: Competing logics and the consolidation of U.S. community banking." Academy of Management Journal 50, no. 4 (2007): 799820.

McPhilemy, S. "Formal Rules Versus Informal Relationships: Prudential Banking Supervision at the FSA before the Crash." New Political Economy 18, no. 5 (2013): 74867.

Mitchell, A. and P. Sikka, "Accounting For Change: The Institutions of Accountancy." Critical Perspectives on Accounting 4, no. 1 (1993): 29-52, doi:10.1006/cpac.1993.1002.

Mitchell, R.K., B.R. Agle, and D.J. Wood, "Toward a theory of stakeholder identification and salience: Defining the principle of who and what really counts." Academy of Management Review 22, no. 4 (1997): 853-86.

Montgomery, B., "European Community's Draft Fifth Directive: British Resistance and Community Procedures." Comparative Labor Law Journal 10, no. 3 (1989): 429-51.

Nasdaq, "Summary of NASDAQ Corporate Governance Proposals." (2002). Accessed 3 November, 2002. http://www.nasdaq.com/about/Corp_Gov_Summary101002.pdf.

Nordberg, D. and T. McNulty, "Creating better boards through codification: Possibilities and limitations in UK corporate governance, 1992-2010." Business History 55, no. 3 (2013): 348-74, doi:10.1080/00076791.2012.712964.

NYSE, "Final NYSE Corporate Governance Rules," New York Stock Exchange. Accessed 15 October, 2006. http://www.ecgi.org/codes/documents/finalcorpgovrules.pdf.

Ocasio, W., "Attention to Attention." Organization Science 22, no. 5 (2011): 1286-96, doi:10.1287/orsc. 1100.0602 .

O'Connor, S., and J. Brunsden. "Businesses Wary of Theresa May's Board Reforms." Financial Times Ltd. Accessed 11 July, 2016, https://www.ft.com/content/09fc53604780-11e6-b387-64ab0a67014c.

ONS, "Ownership of UK Quoted Shares, 2012," UK Office of National Statistics. Accessed 1 February, 2015. http://www.ons.gov.uk/ons/dcp171778_327674.pdf. 
Puxty, A.G., H.C. Willmott, D.J. Cooper, and T. Lowe, "Modes of regulation in advanced capitalism: Locating accountancy in four countries." Accounting, Organizations and Society 12, no. 3 (1987): 273-91, doi:10.1016/0361-3682(87)90041-9.

Rao, H. and S. Giorgi, "Code Breaking: How Entrepreneurs Exploit Cultural Logics to Generate Institutional Change." Research in Organizational Behavior 27 (2006): 269304, doi:10.1016/S0191-3085(06)27007-2.

Soin, K. and C. Huber, "The Sedimentation of an Institution: Changing Governance in U.K. Financial Services." Journal of Management Inquiry 22, no. 3 (2013): 260-80, doi:10.1177/1056492612467510.

Spira, L.F. and J. Slinn. The Cadbury Committee: A History. Oxford: Oxford University Press, 2013.

Suchman, M.C., "Managing legitimacy: strategic and institutional approaches." Academy of Management Review 20, no. 3 (1995): 571-610, doi:10.5465/AMR.1995.9508080331.

Suddaby, R. and R. Greenwood, "Rhetorical Strategies of Legitimacy." Administrative Science Quarterly 50, no. 1 (2005): 35-67.

Thornton, P.H., W. Ocasio, and M. Lounsbury. The Institutional Logics Perspective: A New Approach to Culture, Structure, and Process. Oxford: Oxford University Press, 2012.

Walker, D., "A review of corporate governance in UK banks and other financial industry entities: Final recommendations," HM Treasury. Accessed 26 November, 2009. http://www.hm-treasury.gov.uk/d/walker_review_consultation_160709.pdf.

Winter, J., "Report of the high level group of company law experts on a modern regulatory framework for company law in Europe." 15 Accessed August, 2011. http://ec.europa.eu/internal_market/company/docs/modern/report_en.pdf.

Zajac, E.J. and J.D. Westphal, "The Social Construction of Market Value: Institutionalization and Learning Perspectives on Stock Market Reactions." American Sociological Review 69, no. 3 (2004): 433-57.

Zanot, E.J., J.D. Pincus, and E.J. Lamp, "Public perceptions of subliminal advertising." Journal of Advertising 12, no. 1 (1983): 39-45.

Zattoni, A. and F. Cuomo, "Why Adopt Codes of Good Governance? A Comparison of Institutional and Efficiency Perspectives." Corporate Governance: An International Review 16 no. 1 (2008): 1-15, doi:10.1111/j.1467-8a683.2008.00661.x. 